\title{
PDHX Gene
}

National Cancer Institute

\section{Source}

National Cancer Institute. PDHX Gene. NCI Thesaurus. Code C155317.

This gene plays a role in the localization of the pyruvate dehydrogenase complex. 